Levent Bat, Elif Arıcı, Ayşah Öztekin, Fatih Şahin

Sinop University, Sinop-Turkey

leventbat@gmail.com, elfkarakas@gmail.com, aysahvisne@gmail.com, sahinfth@gmail.com

\begin{tabular}{l|l|l}
\hline \hline DOI & \multicolumn{2}{|l}{ http: //dx.doi.org/10.12739/NWSA.2020.15.1.5A0128 } \\
\hline \multirow{2}{*}{ ORCID ID } & $0000-0002-2289-6691$ & $0000-0001-6359-9194$ \\
\cline { 2 - 3 } & $0000-0002-3726-7134$ & $0000-0003-0605-2672$ \\
\hline CORRESPONDING AUTHOR & Levent Bat \\
\hline
\end{tabular}

\title{
TOXIC METALS IN Engraulis encrasicolus (LINNAEUS, 1758) FROM THE COASTAL WATERS OF SINOP IN THE BLACK SEA
}

\section{ABSTRACT}

The aim of this study is to determine the amounts of As, Cd, $\mathrm{Hg}$ and $\mathrm{Pb}$ in the muscle tissue of Engraulis encrasicolus caught from Sinop coasts of the Black Sea. Metal analysis was performed by ICP-MS. $\mathrm{Pb}$ showed the highest concentration followed by As, Hg and Cd. The presence of four toxic metal levels was determined in the edible tissues of $E$. encrasicolus however, in quantities even below the allowable limits set by the Turkish Food Codex (TFC), EU Commission Regulation and other international standards. As has the highest concentration $(0.13 \mathrm{mg} / \mathrm{kg}$ wet wt.) among the toxic metals as shown in Figure 3 which followed by $\mathrm{Pb}$ and $\mathrm{Hg}$ with levels of 0.09 and 0.055 $\mathrm{mg} / \mathrm{kg}$ wet wt. The highest Cd level was $0.033 \mathrm{mg} / \mathrm{kg}$ wet wt. The total of Target Hazard Quotient values for each element was less than 1 , and it was concluded that anchovy consumption was safe for human health.

Keywords: Engraulis encrasicolus, Black Sea, Sinop Shores, Estimated Daily Intake, Target Hazard Quotient

\section{INTRODUCTION}

In the marine ecosystem, toxic metals are accumulated by fish either directly from water or through their diet or both. However, concentration of bioaccumulation of metals depends on the bioavailability of each element in the surroundings, storage, excretion mechanisms and ingestion rate. Non-essential toxic metals such as cadmium, arsenic, mercury and lead are of no benefit to living organisms and have a detrimental effect. Toxic metal levels in fish can counteract their beneficial effects leading to adverse effects of heavy metals on human health including serious threats such liver damage, cardiovascular diseases, renal failure and even death. Fish is important source of protein, having rich contents of unsaturated fatty acids, essential minerals and vitamins which are essential in people health [1]. The current heavy metal resources of the Black sea are discussed in one of the recent reviews [2]. Pollution loads carried not only by the countries that have a coast to the Black sea but also from Europe, especially the large rivers such Danube flowing into the Black Sea [3], affect this unique ecosystem [4] negatively (Figure 1). Sinop is one of the smallest cities on the Black Sea coast and does not have an industry. Sinop city has been depend on fishing as the main livelihood for the coastal fishermen [5]. Anchovy is the most commercial fish species in the Black sea [6]. It is a preferred fish by humans. They are consumed as frying, steaming, baking, grilling, stuffed rice and so on.

How to Cite:

Bat, L., Arıcı, E., Öztekin, A., and Şahin, F., (2020). Toxic Metals in Engraulis encrasicolus (LINNAEUS, 1758) from The Coastal Waters of Sinop in The Black Sea, Ecological Life Sciences (NWSAELS), 15 (1):9-14, DOI: 10.12739/NWSA.2020.15.1.5A0128. 


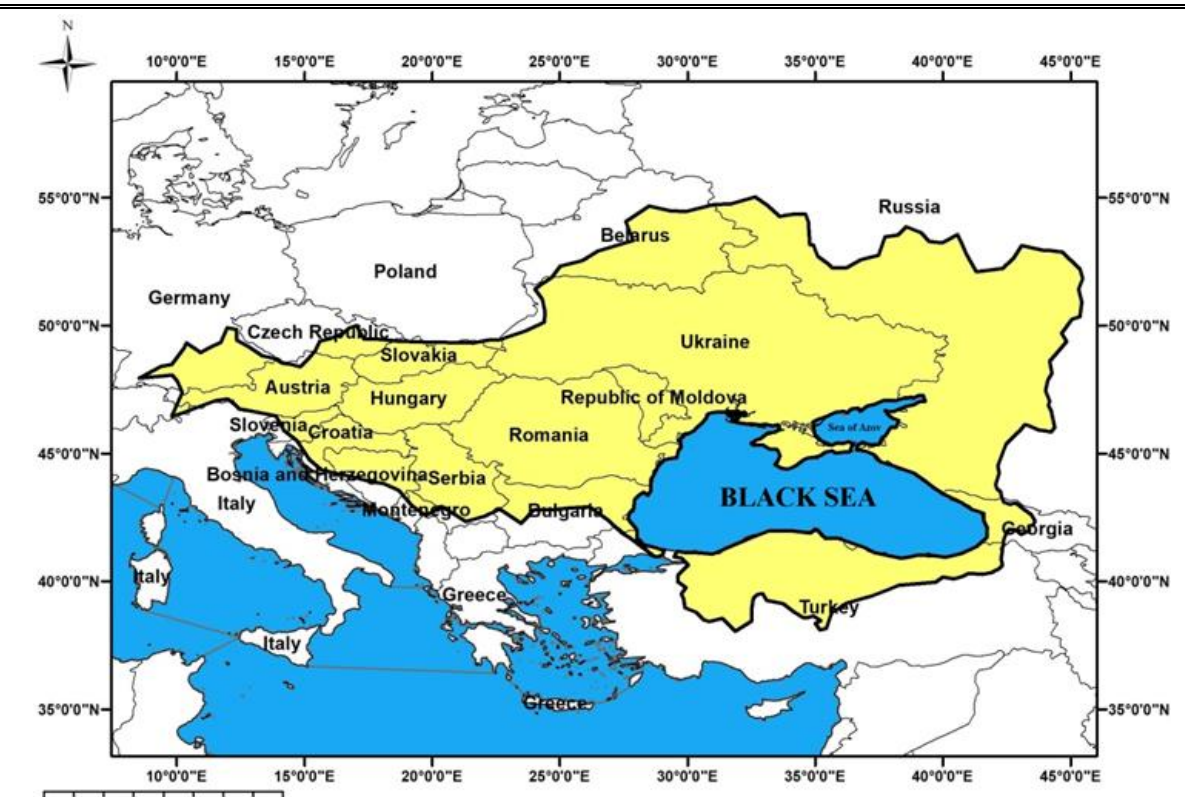

Figure 1. Under the various pollution effect of the Black Sea Basin $[2]$

The aim of this study is to determine the concentration of As, $\mathrm{Cd}$, $\mathrm{Hg}$ and $\mathrm{Pb}$ in the edible tissues of Engraulis encrasicolus caught in Sinop coasts of the Black sea and if the metal levels are within the permissible limits set by the Turkish Food Codex (TFC) [7 and 8] EU Commission Regulation [9 and 10], Georgian Food Safety Rules [11] and GAIN Report Russian Federation [12]. In addition, health risks of these toxic metals were consumed by people who consumed anchovy.

\section{RESEARCH SIGNIFICANCE}

In this investigation, concentrations of four toxic heavy metals (As, $\mathrm{Pb}, \mathrm{Hg}$ and $\mathrm{Cd}$ ) in Engraulis encrasicolus from Sinop coasts of the southern Black sea and calculate indices of human health risk related to the consumption of its edible tissues.

\section{MATERIALS AND METHODS}

In this study, anchovy samples that were caught during the 2017 fishing season in Sinop coasts (Figure 2) were purchased from fishing markets. Total lengths of specimen were recorded from the fish samples and rinsed in clean water. The anchovies were between 8 and $12 \mathrm{~cm}$ in length. Fresh fish specimens were dissected using a sharp plastic knife, removing edible tissues of the fish and sealed in a plastic bag. A total of 100 individuals were analyzed, 25 for each sampling month. All samples were put deep frozen at $-21^{\circ} \mathrm{C}$ till their analysis. Metal analysis in anchovy was performed using m-AOAC 999.10- ICP/MS method by accredited Environment Industrial Analysis Laboratory Services Trade Company (TÜRKAK Test TS EN ISO IEC 17025 AB-0364-T). The method for determination of elements, used acid, standard reference material, wet digestion was used by European standard method with number EN 15763. The limits of detection used for analysis of arsenic, cadmium, mercury and lead were 0.05, 0.03, 0.05 and 0.05, respectively. 


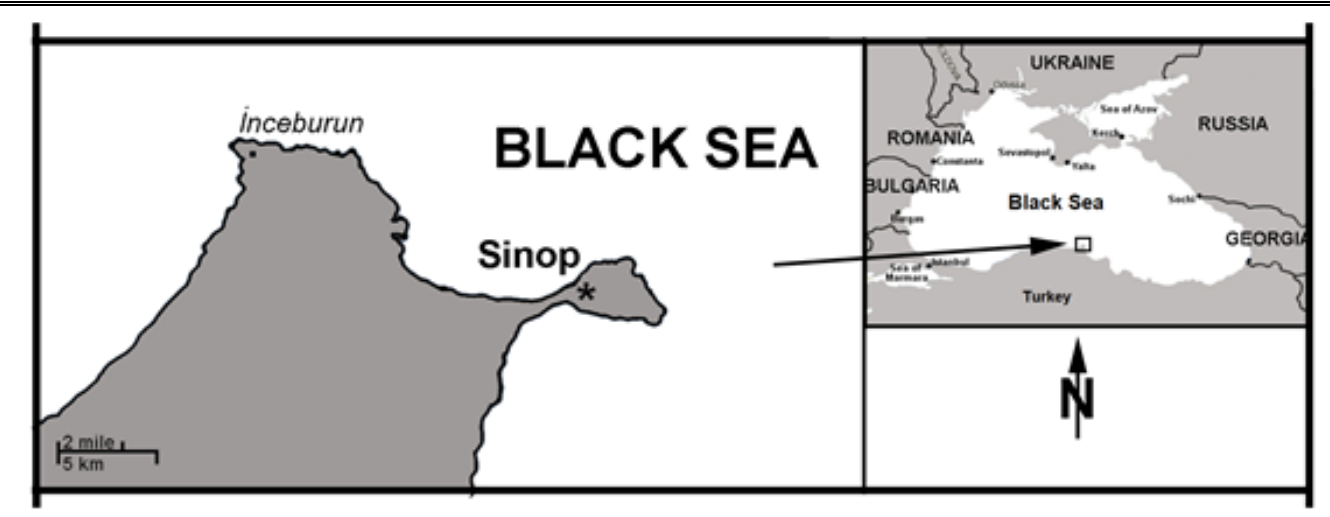

Figure 2. The study area, Sinop coasts of the Black Sea

\subsection{Assessments Target Hazard Quotient (THQ) of Heavy Metals in Anchovy}

Hazard from metals entering owing to ingestion may be defined using a THQ as the rate of the estimated daily intake (EDI) $\mathrm{mg} / \mathrm{kg}$ of body wt. and the reference dose (RfD $\mathrm{mg} / \mathrm{kg}$. ). The THQ was computed by using the equation below [13]:

$\mathrm{THQ}=\mathrm{EDI} / \mathrm{R} f \mathrm{D}$

The EDI depends on both the metal amount and the quantity of consumption of anchovy. The EDI of metals was calculated using the equation below:

$\mathrm{EDI}=\mathrm{C}_{\text {metal }} \times_{\text {Wanchovy }} / \mathrm{BW}$

Where: $C_{\text {metal }}$ is the metal levels in anchovy; $W_{\text {anchovy }}$ represents the daily mean consumption of fish; Bw is the body weight of an adult $(\mathrm{kg})$. Wanchovy represents the daily mean ingestion of fish is given as: 0.013 for infants, 0.027 for children and 0.041 for adults (kg/day); Bw is the body weight of $10 \mathrm{~kg}$ for infants, $30 \mathrm{~kg}$ for children and 70 $\mathrm{kg}$ for adults [14]. According to the Risk Assessment Information System (RAIS) and [16] U.S. Environmental Protection Agency (USEPA) the Rf. D for As, $\mathrm{Hg}, \mathrm{Cd}$ and $\mathrm{Pb}$ are $0.0003,0.0003,0.001$ and $0.0035 \mathrm{mg} / \mathrm{kg} / \mathrm{day}$, respectively [15 and 16].

The sum of THQs calculated for each element gives TTHQs.

$\mathrm{TTHQ}=\mathrm{THQ}(\mathrm{As})+\mathrm{THQ}(\mathrm{Pb})+\mathrm{THQ}(\mathrm{Hg})+\mathrm{THQ}(\mathrm{Cd})$.

If TTHQ>1.0, so the EDI of a certain element overruns the RfD, pointing out that there is a possible hazard associated with that element. Statistical analysis was performed using the SPSS, version 21. One-way ANOVA with post hoc test analyses based on Tukey was used to compare the difference between the concentrations. P-value of $<0.05$ or less was considered statistically significant [17].

\section{RESULTS AND DISCUSSION}

Results showed that As has the highest concentration $10.13 \mathrm{mg} / \mathrm{kg}$ wet wt. in October) among the toxic metals as shown in Figure 3 which followed by $\mathrm{Pb}$ and $\mathrm{Hg}$ with levels of 0.09 and $0.055 \mathrm{mg} / \mathrm{kg}$ wet wt. in December. The highest cd level was $0.033 \mathrm{mg} / \mathrm{kg}$ wet wt. in October. Oneway analysis of variance showed that there were significance differences $(\mathrm{p}<0.05)$ in the amounts of four toxic metals in the edible tissues of anchovy. 


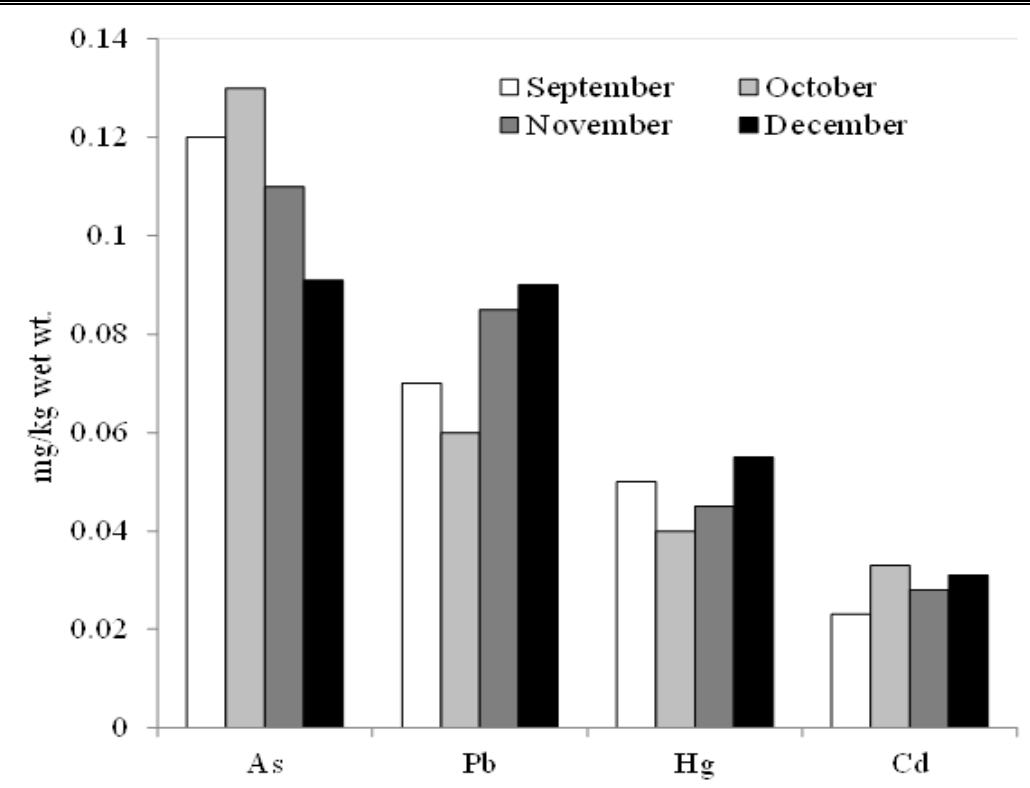

Figure 3. As, $\mathrm{Pb}, \mathrm{Hg}$ and $\mathrm{Cd}$ in the edible tissues of E. enrasicolus from the Black Sea coasts in fishing season of 2017

The calculated EDI, THQ and TTHQ values of anchovy from Sinop coasts in the Black Sea for infants, children and adults are presented in Table 1 .

Table 1. Estimated Daily Intakes (EDI), Target Hazard Quotients (THQ) and Total Target Hazard Quotients (TTHQ) of toxic metals in edible tissues of anchovy from the Black Sea

\begin{tabular}{|c|c|c|c|c|c|c|}
\hline \multirow{2}{*}{$\begin{array}{c}\text { Toxic } \\
\text { Metals }\end{array}$} & \multicolumn{2}{|c|}{ EDI mg/day/kg body wt. } & \multicolumn{3}{c|}{ THQ } \\
\cline { 2 - 7 } & Infants & Children & Adults & Infants & Children & Adults \\
\hline $\mathrm{As}$ & 0.0001465 & 0.0001014 & 0.0000660 & 0.48858 & 0.33825 & 0.22013 \\
\hline $\mathrm{Pb}$ & 0.0000991 & 0.0000686 & 0.0000446 & 0.33041 & 0.22875 & 0.14886 \\
\hline $\mathrm{Hg}$ & 0.0000617 & 0.0000427 & 0.0000278 & 0.06175 & 0.04275 & 0.02782 \\
\hline $\mathrm{Cd}$ & 0.0000380 & 0.0000263 & 0.0000171 & 0.01086 & 0.00752 & 0.00489 \\
\hline \multicolumn{9}{|c|}{ TTHQ $=$} & 0.89160 & 0.61727 & 0.40170 \\
\hline
\end{tabular}

Results of the present study show low metal amounts than the maximum permissible limits in anchovy as recommended by national and international regulations (Table 2), indicates that levels of these metals in the edible tissues of anchovy may not considered toxic and imply to be safe for people consumption as shown on Table 1. Metal amounts may vary among individuals depending on their feeding habits, habitats, age, size and length of the fish and seasons [18]. As, Pb, $\mathrm{Hg}$ and $\mathrm{Cd}$ are important toxic metals that no play role in biochemical process for fish.

Table 2. The tolerable values of measured toxic metals in the edible tissues of fish (mg/kg wet wt.)

\begin{tabular}{|l|c|c|c|c|}
\hline Standards & As & Cd & Pb & Hg \\
\hline Turkish Food Codex [7] & -- & 0.1 & 0.4 & 0.5 \\
\hline Turkish Food Codex [8] & -- & 0.05 & 0.3 & 0.5 \\
\hline EU Commission Regulation [9] & -- & 0.05 & 0.3 & 0.5 \\
\hline EU Commission Regulation for anchovy [10] & -- & 0.25 & -- & -- \\
\hline Georgian Food Safety Rules [11] & 2.0 & 0.2 & 1.0 & 0.5 \\
\hline GAIN Report Russian Federation [12] & 2.0 & 0.2 & 1.0 & 0.5 \\
\hline Australia and New Zealand Food Standards [13] & 2.0 & -- & 0.5 & 0.5 \\
\hline
\end{tabular}


The UK previously imposed a limit of $1 \mathrm{mg} / \mathrm{kg}$ for arsenic in food with separate limits applicable to certain food categories. These regulations were revoked in 2002. There is no maximum level set for arsenic in foods at TFCs [7 and 8] and EU regulations [9 and 10] levels. However, the tolerated arsenic values of other international organizations [11, 12 and 13] are shown in Table 2. In this study, the amounts of $\mathrm{As}, \mathrm{Pb}, \mathrm{Hg}$ and $\mathrm{Cd}$, which are toxic in the consumed muscles of anchovy, were found to be below the values approved by national and international organizations [7, 8, 9, 10, 11, 12 and 13]. When the results of this study are compared with other studies, it is seen that toxic metal levels in anchovy are generally lower or in similar to those in recent reviews [19, 20 and 21].

\section{CONCLUSION AND RECOMMENDATIONS}

The present study also focused on these toxic metal amounts in anchovy muscles since most of the local people include this portion in their daily diet in which for average infants (10 $\mathrm{kg}$ body wt.), children (30 kg body wt.) and adults ( $70 \mathrm{~kg}$ body wt.). Calculated THQ values for each toxic metal are given in Table 1. The sum of THQ values obtained from these results was found to be lower than 1 for infants, children and adults. Considering that the weight of the infants is low, it is normal to have high values compared to children and adults. The amount specified by internationally authorized institutions and organizations is the consumption of two portions of fish per week. We believe that paying attention to this will be beneficial for health. Based on the results of the present study four toxic metal levels are present, however, in small quantities. It is known that the muscle is not an active tissue in accumulating metals. Since all these metal amounts are less than the values described by TFC and is considered safe for consumption.

\section{CONFLICT OF INTEREST STATEMENT}

The authors declare no conflict of interest.

\section{REFERENCES}

[1] Bat, L., (2019). One Health: The Interface Between Fish and Human Health. Current World Environment. 14(3):355-357.

[2] Bat, L., Öztekin, A., Şahin, F., Arıcı, E., and Özsandıkçı, U., (2018). An overview of the Black Sea pollution in Turkey. MedFAR. 1:67-86.

[3] Mee, L.D., (1992) The Black Sea in Crisis: A Need for Concerted International Action. Ambio. 21(4):278-286.

[4] Zaitsev, Y., (2008) An introduction to the Black Sea ecology. Smil Editing and Publishing Agency Ltd. Odessa. Pp:228.

[5] Bat, L., Sezgin, M., Şahin, F., Birinci Özdemir, Z., and Ürkmez, D., (2013). Sinop city fishery of the Black Sea. Marine Science. $3(3): 55-64$.

[6] Bat, L., Erdem, Y., Ustaoglu-Tırıl, S., and Yardim, Ö., (2011). Fish Systematic. Ankara: Nobel Yayin Dagitim Ltd. Sti. pp. 272.

[7] Turkish Food Codex, Official Gazette of Republic of Turkey., (2002). Notifications About Determination of the Maximum Levels for Certain Contaminants in Foodstuffs of Turkish Food Codex (in Turkish), (Notification No: 2002/63), iss. 24885.

[8] Turkish Food Codex, Official Gazette of Republic of Turkey. (2009). Notifications Changes to the Maximum Levels for Certain Contaminants in Foodstuffs (in Turkish), (Notification No:2009/22), iss. 27143.

[9] Commission Regulation (EC), (2006). Official Journal of the European Union. Setting Maximum Levels for Certain Contaminants 
in Food Stuffs. Commission Regulation (EC) No 1881/2006, 364:524 .

[10] Commission Regulation (EU), (2014). No 488/2014 of 12 May 2014 Amending Regulation (EC) No $1881 / 2006$ as Regards Maximum Levels of Cadmium in Foodstuffs, L $138 / 75$.

[11] Georgian Food Safety Rules, (2001). Fish, Other River/Sea Products and Products Made from Them. SanPiN-2.3.2.560-96. The Minister's Decree 16/08/2001 N301/n for Health, Labour and Social Affairs.

[12] GAIN (Global Agriculture Information Network) Report, (2002). Russian Federation Sanitary/Phytosanitary/Food Safety Russian Sanitary Rules and Norms. GAIN Report \#RS2010. SanPiN-96. USDA Foreign Agricultural Service. Gossanepidnadzor Department of the Ministry of Public Health Care of Russia.

[13] U.S. Environmental Protection Agency, (2000). Supplementary Guidance for Conducting Health Risk Assessment of Chemical Mixtures. National Center for Environmental Assessment, Washington, DC, EPA/630/R00/002.

[14] UNSCEAR (United Nations Scientific Committee on the Effects of Atomic Radiation), (2010). Sources and Effects of Ionizing Radiations, UNSCAR 2008 Report to General Assembly with Scientific Annexes Volume I. United Nations, New York.

[15] The Risk Assessment Information System (RAIS), (2019). University of Tennessee, Available at: https://rais.ornl.gov/index.html

[16] U.S. Environmental Protection Agency, (IRIS), Lead., (2005). Washington, DC. Integrated Risk Information System, Available at: http://www.epa.gov/iris/

[17] Zar, J.H., (1984). Biostatistical analysis. Prentice Hall, Int., New Jersey. pp: 718 .

[18] Bat, L., Sezgin, M., Üstün, F., and Şahin, F., (2012). Heavy Metal Concentrations in Ten Species of Fishes Caught in Sinop Coastal Waters of the Black Sea, Turkey. Turkish Journal of Fisheries and Aquatic Sciences. 12:371-376.

[19] Bat, L., (2017). The Contamination Status of Heavy Metals in Fish from the Black Sea, Turkey and Potential Risks to Human Health. In: Sezgin, M., Bat, L., Ürkmez, D., Arıcı, E., Öztürk, B. (Eds.) Black Sea Marine Environment: The Turkish Shelf. Turkish Marine Research Foundation (TUDAV), Publ. No:46, Istanbul, TURKEY. pp. 322-418.

[20] Bat, L., (2017). Pollution and Fishing. In: Black Sea and Fishing Workshop Book/ M. Sezgin, F. Şahin, U. Özsandıkçı (Eds). University of Sinop 13. Bilimsel Yayın. Simal Ajans. Pp:17-54. (in Turkish).

[21] Bat, L. and Arıcl, E., (2018). Chapter 5. Heavy Metal Levels in Fish, Molluscs, and Crustacea from Turkish Seas and Potential Risk of Human Health. In: Holban AM, Grumezescu AM. (Eds.) Handbook of Food Bioengineering, Volume 13, Food Quality: Balancing Health and Disease. Elsevier, Academic Press. pp. 159196. 